\title{
From Spatial Keynesianism to Post-Fordist Neoliberalism: Emerging Contradictions in the Spatiality of the Irish State
}

\author{
Proinnsias Breathnach \\ Department of Geography and National Institute for Regional and Spatial \\ Analysis, National University of Ireland Maynooth, County Kildare, Ireland; \\ proinnsias.breathnach@nuim.ie
}

\begin{abstract}
The transition from Fordism to post-Fordism has been accompanied by profound changes in the spatiality of west European states. The hierarchical, top-down and redistributive structures that typified the Fordist welfare state have been replaced by more complex spatial configurations as elements of economic and political power have shifted both downwards to subnational territorial levels and upwards to the supranational level. A major debate has developed around the nature of these emerging forms of state spatiality and of the processes underpinning their formation. This paper examines how these processes have operated in the particular case of the Republic of Ireland. Here, the spatiality of the state was founded on a peculiar post-colonial combination of a localised populist politics and a centralised state bureaucracy. While this arrangement was quite suited to the spatial dispersal of industrial branch plants which underpinned regional policy in the 1960s and 1970s, it has become increasingly problematic with the more recent emergence of new trends in the nature and locational preferences of inward investment. This is reflected in the profound conflicts that have attended the formulation and implementation of the National Spatial Strategy, introduced in 2002. The result is a national space economy whose increasing dysfunctionality may now be compromising the very development model upon which Ireland's recent spectacular economic growth has been built.
\end{abstract}

Keywords: state spatiality, spatial Keynesianism, Ireland, National Spatial Strategy, gateway cities

\section{Introduction}

As defined by Brenner (2004a), the term "state spatiality" combines both the geographical configuration of a state's territory (its external and internal boundaries and the territorial organisation of its political and administrative systems) and the spatial dimensions of the state's intervention in socioeconomic processes within that territory, including both spatially targeted interventions and indirect spatial effects of aspatial actions. In capitalist states, such configurations evolve in order to facilitate the interests of hegemonic elements in prevailing regimes of capital accumulation (Jessop 1990) and remain quite stable

Antipode Vol. 42 No. 5 2010 ISSN 0066-4812, pp 1180-1199

doi: $10.1111 /$ j.1467-8330.2010.00798.x

(C) 2010 The Author

Journal compilation (c) 2010 Editorial Board of Antipode. 
during the period of dominance of a particular accumulation regime: Harvey's (1982) celebrated "spatial fix". New accumulation regimes tend to emerge in response to major shifts in technology and/or sociopolitical conditions, and seek to put in place new spatial structures which, responding to both the threats and opportunities presented by these shifts, serve to facilitate regime legitimation, the reproduction of labour and, above all, the production and circulation of capital. However, these new spatial structures are superimposed on inherited configurations and are modified by them. The organisation of state space at any historical conjuncture therefore represents a multilayered territorial mosaic involving the interweaving of political geographies established at different moments of historical time.

The transition, in the 1970s and 1980s, from the Fordist regime of accumulation built around the mass-producing welfare state to a postFordist regime of flexible neoliberalism is widely associated with a profound restructuring of state spatialities throughout western Europe, whereby the centralised Fordist welfare state, oriented to the spatial equalisation of living standards and employment opportunities within its borders, was replaced by a decentralised neoliberal state wherein regional economies pursued their own economic interests through direct participation in the global economy. This paper seeks to establish the applicability of this broad model to the evolving spatiality of the Irish state over the period in question. The next section of the paper reviews a range of interpretations that have been placed on the restructuring of state spatialities in western Europe which accompanied the transition to postFordist neoliberalism. The following sections examine, respectively, how the colonial experience profoundly shaped the spatiality of the Irish state that emerged from the independence struggle of the early twentieth century and how the attraction of inward investment in the 1960s and 1970s was accompanied by a policy of branch plant dispersal that amounted to an almost extreme version of the spatial equalisation described by Brenner. The inherent inadequacies of this policy were brought into sharp focus by new spatial tendencies flowing from the spectacular upsurge of the Irish economy in the 1990s, leading to the formulation of a National Spatial Strategy (NSS), the key features of which closely followed Brenner's depiction of post-Fordist neoliberal decentralisation. However, this strategy immediately ran aground on the rocks of the inherited spatiality of the Irish state whose fundamental features were directly incompatible with the strategy in question. The nature and implications of the contradictions underlying this mismatch between existing and projected spatialities are discussed in some detail before the paper concludes with some observations on how the Irish experience contributes to contemporary debates on state restructuring in Europe. 


\section{Fordist and Post-Fordist State Spatialities in Western Europe}

The form of Fordism that emerged in western Europe in the decades after the Second World War was characterised by centralised state systems presided over by social democratic governments committed to the maintenance of mass collective consumption via welfare transfers and public service provision. In the economic sphere, such governments practised conventional Keynesian macroeconomic management while implementing industrial policies formulated at a national level, practices which were rendered feasible by the fact that most west European economies at this stage were largely self-contained, in that economic production, for the most part, was in the hands of indigenous enterprises and primarily served domestic markets (Brenner 2004b). Problems of spatially uneven economic development were generally addressed through standardised policies involving measures to encourage the establishment of industrial branch plants in "lagging" regions (Brenner 2004a; Stöhr 1989). This combination of welfare transfers, public service provision and branch-plant industrialisation constituted a form of "spatial Keynesianism" designed to equalise living standards and employment opportunities between regions (Brenner 2004b). In this system, the main functions of local and regional government were delivery of centrally funded public services and application of central government socioeconomic policies within their operational districts (Loughlin 2001a). Thus, the dominant feature of the spatiality of west European states was a strongly hierarchical (but spatially equalised, in socioeconomic terms) structure, with local government units nested within the territories of regional government (where this existed) in an integrated national jurisdictional system dominated by the institutions of the central state.

The prolonged period of stagnation and recession during the 1970s and 1980s ushered in a powerful swing to the right in European politics, leading to the widespread election of conservative governments pursuing neoliberal economic programmes involving the dismantling of the welfare state, the primacy of monetary over employment policy, privatisation, deregulation and an emphasis on fostering entrepreneurialism through supply-side economic policies (Brenner 2004b). This political turn at the national level was accompanied, in virtually all European Union member states, by the transfer, to a greater or lesser extent, of political and/or administrative functions from the national to regional and/or local levels (Loughlin 2001a; Parkinson, Harding and Dawson 1994). To an extent, and in some cases, this trend can be attributed to bottom-up demands for political devolution and/or the desire on the part of central governments to create more flexible and effective systems of public administration (Gualini 2004; Keating 1998; 
Parkinson, Harding and Dawson 1994). There have also been suggestions that the transfer of greater responsibility for their own affairs to regional and local governments is an inevitable consequence of the inability of the national state to maintain its former level of welfare-state activity in the face of fiscal pressures and the rollback of the state as part of the neoliberal agenda (Brenner 2004b; Jones 2001; Loughlin 2001a).

This functional and fiscal contraction of central governments and the associated transfer of capabilities to the subnational level have in turn been seen as part of a broader process of "hollowing out" (Jessop 1994) whereby European states have been progressively losing their former capacity to control affairs within their own borders (Brenner 1998). Other key factors in this process have been the concession of powers and functions to the European Union (which in turn has itself been seeking to strengthen the position of subnational regions vis-à-vis national governments within member states) and other supranational organisations (Gualini 2004; Loughlin 2001b) and the impact of accelerated globalisation (facilitated in large part by the liberalisation of international trade and investment-itself a consequence of the neoliberal political turn) on the capacity of national governments to regulate economic activity within their borders (Held et al 1999; Ohmae 1995).

There has been considerable debate over the extent to which hollowing-out has actually led to a real diminution of the political capacity of national governments or whether there has instead been a spatial rescaling of the ways in which governments operationalise their powers (Jones 2001; MacKinnon and Phelps 2001). In particular, a substantial literature has been generated around the proposition that administrative and political decentralisation has been pursued by national states as part of a strategy for strengthening the capacity of national economies and their constituent spatial units to compete in the global marketplace. The decline of older industrial regions that accompanied the collapse of Fordism and the increasing concentration of newer forms of economic activity in metropolitan regions at both national and European levels have created demands for new types of policies for stimulating development in regions outside the immediate influence of these core areas (Brenner 2004b). The combination of the neoliberal stress on self-reliance, competitiveness and entrepreneurialism, the emergence of new regional development thinking emphasising endogenous growth, cluster promotion and learning and innovation systems (MacLeod 2001) and accelerating international flows of foreign direct investment has prompted the formulation of policies and programmes designed to foster the creation of regionally coherent economic and business structures capable of competing for export markets and mobile investment. Typically, these have involved the devolution to regional and local governments of 
new revenue-raising powers and planning and economic development functions; the creation of new governance structures at the regional level involving "development coalitions" embracing local government, business interests and other stakeholders; infrastructural investments designed to enhance the attractiveness of areas to potential inward investors; and increasing competition between regions for mobile investment.

The decentralisation of government functions can therefore be seen as a centrally devised strategy designed to enhance aggregate national competitiveness with respect to the global economy. This viewpoint is supported by the adoption, in 1999, by the EU member states of the tenets of the European Spatial Development Perspective (ESDP), a policy framework for guiding spatial planning and development within the EU (Committee on Spatial Development 1999). The key aim of the ESDP is the achievement of economic and social cohesion across the EU in a way that is economically, culturally and environmentally sustainable. The main mechanism for achieving this is to supplant national and regional hierarchical core/periphery systems with a more balanced, "polycentric", urban system wherein regional urban centres would articulate distinctive regional economies, which in turn would be integrated directly into the global economy rather than into their respective national economies as had hitherto been the case. In developing direct links to the global economy, regional centres would act as "gateway" cities, through which flows of investment and information would diffuse through the regional hinterland. The ESDP, therefore, conflates regional and urban development policy into a single spatial strategy for territorial development based on the city-region as focal unit (Ward and Jonas 2004). This approach fits well with Brenner's (1998:5) view that city-regions are once again regaining the role of "geo-economic engines of the world system" which they previously possessed before the formation of the modern world system of territorial states.

The various change processes identified here, including globalisation, the growing role of supranational organisations, the hollowing out of the national state, functional devolution to the regional level and the increasing participation of regional economies in global markets and production systems, have inevitably engendered profound changes in the spatiality of west European states (Loughlin 2001b). The relatively straightforward nested hierarchies of power that characterised the Fordist state have been replaced by new structures of great complexity:

The current period of globalization involves a proliferation of spatial scales, their relative dissociation in complex tangled hierarchies (rather than a simple nesting of scales), and an increasingly convoluted mix 
of scale strategies as economic and political forces seek the most favourable conditions for insertion into a changing international order (Jessop 2002:112).

While the actual configurations emerging from this diverse mix of tendencies vary from case to case, depending on "the specific restructuring strategies adopted by modernising political alliances within each national and local context" (Brenner 2004b:474), one recurring theme has been the "growing 'territorial non-coincidence' ... between the scales on which capital accumulation and state territorial power are organized" (Brenner 1998:4) as regional economies become increasingly interconnected in international networks (Gualini 2004). While this has inevitably weakened the regulatory capacity of national states, they still retain considerable functionality, and continue to play the key role of providing an institutional framework (and, to an extent, financial assistance) to allow city-regions to enhance their capabilities of attracting mobile investment and competing in the global economy (Brenner 1998; Ward and Jonas 2004).

The paper now turns to an investigation of the changing spatiality of the Irish state in the light of the general themes and trends identified in the foregoing section.

\section{The Spatiality of the Irish State}

What is now the Republic of Ireland (referred to as "Ireland" in the remainder of this paper) could be regarded as the last case of western Europe's nineteenth century nation-state formation episode, following its securing of effective formal political independence in 1922. However, almost alone among western Europe's nation states, the Irish state had emerged from several hundred years of colonial control, during which period its economy had become thoroughly extraverted (Amin 1976) in contrast to the autocentric structures which were the norm elsewhere in the region (Breathnach 1988; Mjøset 1992). Thus, production was largely confined to agricultural produce for export to Britain, with industrial goods being imported in return. This simple fact shaped the spatiality of the colonial economy: interregional trade was minimal; provincial urban centres acted as collecting points for agricultural products and distribution points for industrial goods and as administrative outposts of the colonial administration. The latter was centred in Dublin which also served as the main port for external trade and comprised a classic colonial primate city that dominated the urban system in terms of size and range of functions.

In class terms, the economy was dominated by petty capital in the form of commercial farmers and associated urban-based merchants and professionals. Ireland's lack of industrialisation (outside the northeast which had remained within the UK) and long history of mass 
outmigration meant there was neither an organised working class nor the kind of industrial bourgeoisie which had come to assume a high degree of state control in many of Europe's early industrialising nations (Gill 2008; Kirby 1997). Colonial politics having been dominated by the recently eliminated landlord class, the petty bourgeoisie had little experience of party politics apart from their involvement in the county councils that were the central element in the system of local government introduced in 1898, an involvement that tended to confirm the highly localised horizons and political ambitions of this key social group.

Party politics in Ireland crystallised around the two main parties (Fianna Fáil and Fine Gael) that emerged from the fragmentation of the national movement in the aftermath of independence. While appealing to different segments of the social structure, these were both essentially populist and pragmatic parties without a clear political programme - a common phenomenon in postcolonial states that lack the social structure to support class-based politics (Kirby 1997). Given the highly localized orientation and limited political ambitions of the main political parties, from the beginning the state bureaucracy came to occupy a powerful position in the configuration of the Irish state. This consisted essentially of the former British colonial administration which had survived almost intact the transition to independence. This was a highly centralised, well-organised and competent bureaucracy which had no experience of political accountability within Ireland and little contact with local civil society, and whose colonial function of conservative managerialism became the hallmark of its administrative approach in the newly independent state.

In its new guise as the civil service of the fledgling Irish state, this bureaucracy found itself dealing with a parliament and government whose membership was mainly drawn from rural and small-town Ireland and had a limited interest in, and capacity for, national-level government. Given its established expertise in this area, therefore, the civil service assumed a level of autonomy and degree of control over the administration of the central state which was unique in western Europe (Breen et al 1990). From the beginning, Irish parliamentary democracy assumed a "clientelist" form (Hazelkorn 1986), with parliamentary representatives seeing it as their main function to act as intermediaries between their local constituents (or "clients") and the offices of the central state with respect to routine concerns such as access to government grants, social welfare entitlements and medical services (a function which grew in importance as the rudiments of a welfare state were put in place in the 1950s and 1960s).

The Irish state, therefore, can be characterised as combining a highly localised party politics and a highly centralised system of public administration (Laffan 1996). The local government system introduced 
in 1898 had limited powers and functions, with most public services being delivered directly from the central state. Both parliamentary representatives and state bureaucrats share a deep-seated opposition to the strengthening of local government due, in the case of the latter, to their profoundly centralist tendencies and, in the case of the former, to the fact that a strengthened local government would tend to undermine their role as local/central intermediaries (Breathnach 1992). Indeed, while the general tendency in the second half of the twentieth century was for west European states to progressively devolve public service functions to subnational tiers of government (Sharpe 1988), in Ireland the reverse occurred, with several key functions (health, main roads, agricultural extension) being transferred from local government to the central state. Thus, today Ireland has one of the most centralised systems of government in the world (Laffan 1996), with the activities of local government being largely confined to environmental maintenance, upkeep of local roads, control of physical development and a greatly reduced social housing function. This is reflected, in spatial terms, in the disproportionate concentration of population in the East (Dublin and adjacent counties) region (39\% of the national total in 2006) and particularly in the concentration of decision-making functions (56\% of managers and executives) and high-level services (65\% of employment in banking and finance).

\section{Spatial Keynesianism, Irish-style}

One consequence of the intense localism of the Irish political process is that all central government measures are evaluated by politicians, not necessarily on their general merits, but on how they are likely to impact on local constituencies. As a result, it has generally been difficult, if not impossible, for the central government to introduce measures that have a wide impact which is spatially selective (eg rationalisation of hospital services). This was brought into sharp relief by the growing influx of foreign direct investment that materialised following the adoption by the Irish government, in the late 1950s, of a policy of promoting exportoriented industrialisation via such investment. A major debate ensued concerning the locational policy that should be applied to incoming branch plants, with expert opinion favouring spatial concentration in a limited number of "growth centres" (Breathnach 1982). However, when a major state-sponsored consultants' report (Colin Buchanan and Partners 1968) advocated such an approach, a public outcry emanating from areas not favoured by the report caused the government to shy away from its proposals. In fact, with Ireland's entry to the EU in 1973 expected to lead to a further acceleration of inward investment, in the preceding year the Irish government published a set of Regional Industrial Plans for the period 1973-77, which envisaged an almost 
extreme form of the "industrial decentralization, urban deconcentration and spatial equalization" that Brenner (2004b:460) regarded as typifying Fordist regional policies in western Europe.

These plans were formulated and implemented by the Industrial Development Authority (IDA), the state agency responsible for attracting foreign investment to Ireland and which, in 1969, had also been given responsibility for regional industrial development within the country. The IDA regional plans brought spatial engineering to an unprecedented level of specification (Breathnach 1982). Not only was an industrial job creation target for the plan period set for each of the nine Irish planning regions, but within each region, neighbouring towns were assigned to clusters, for each of which a job creation target was also set. In all, 58 such clusters were identified, embracing a total of 209 towns and villages. The principal mechanism used by the IDA for achieving its job creation targets was a major programme of readybuilt "advance" factory construction under which 746,000 $\mathrm{m}^{2}$ of factory floor space was constructed in 156 different locations between 1972 and 1982 (the planning approach adopted for 1973-77 was continued for the 1978-82 period). The distribution of this floor space was almost perfectly correlated with the population of the recipient towns, indicating that the IDA was attempting to allocate new industrial jobs in accordance with the population - the ultimate in spatial equalisation of access to industrial employment. The IDA's regional plans therefore represented a perfect example of the "redistributive spatial policies designed to alleviate intra-national territorial inequalities by extending urban industrial growth into underdeveloped, peripheral regions" which, according to Brenner (2004a:2), were put into effect by most western European states during the 1960s.

The 1970s witnessed a remarkable regional redistribution of manufacturing employment in Ireland, with new inward investment (which accelerated following EU entry) being guided mainly to nonurban areas, especially in the west of Ireland, while established (and mainly indigenous) industry, which was concentrated in the larger urban centres and had been established with a high level of tariff protection, contracted significantly with exposure to external competition following EU entry. Thus, while the previously unindustrialised western areas, where the highest level of regional aid was available, experienced 45\% growth in manufacturing employment between 1971 and 1981, there was virtually no growth in the rest of the country. Figure 1 shows how the very substantial inter-regional differences in the distribution of manufacturing industry which existed in 1961 had been greatly reduced by 1981. In particular, whereas in 1961 the East (ie Dublin) region's share of national manufacturing employment was $64 \%$ higher than its share of population, by 1981 this had been reduced to just $3 \%$. 
田1961 圈 1981

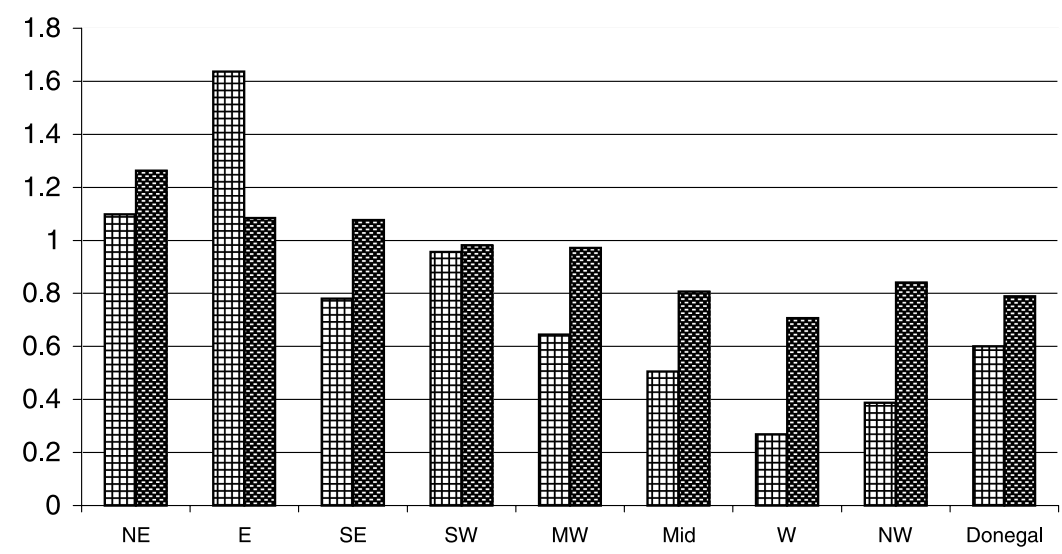

Figure 1: Ratio of population share to manufacturing employment share, Irish planning regions (see Figure 2 for a map of planning regions)

\section{Spatial Impact of the "Celtic Tiger"}

In the 1980s, the Irish economy was badly affected by international recession associated with post-Fordist economic restructuring, and at the end of the decade per capita GDP stood at just two thirds of the then EU average. However, the early 1990s ushered in a prolonged period of high economic growth which pushed the country to the EU forefront in terms of per capita GDP. The key factor in the creation of the so-called "Celtic Tiger" economy was a major surge in new inward investment in both manufacturing (real output in foreign manufacturing plants grew threefold between 1991 and 2000) and export services (mainly software, financial services and back-office activities), whose share of foreignfirm employment rose from just 5\% in 1989 to $35 \%$ in 2001 (Breathnach 2007a).

While most areas of the country experienced substantial growth in employment and incomes during the boom years of the 1990s, this period saw a significant further enhancement of the East region's already dominant position within the Irish space economy. Services had now become by far the main source of employment growth, and as shown earlier in this paper, high-level service employment was disproportionately concentrated in the East region. Of even greater significance was the very high level of concentration (75\% in 2000) in the East region of employment in the rapidly expanding export services sector.

\section{The National Spatial Strategy}

By the turn of the new century, therefore, the Irish government was coming under increasing pressure to address a double-edged 


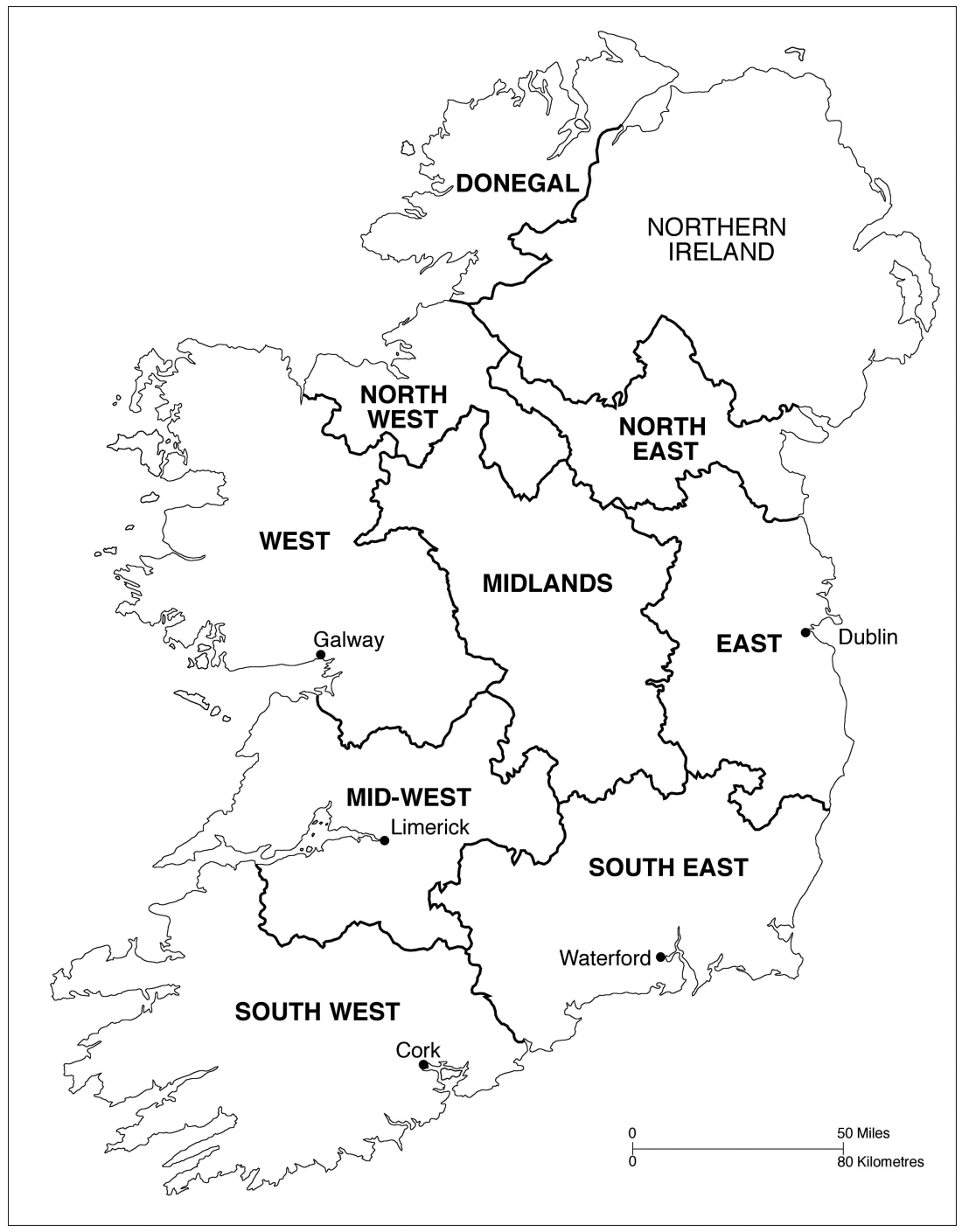

Figure 2: Irish planning regions (pre-1987)

regional problem: increasing congestion in the East region due to poorly planned rapid growth, and substantial (and growing) income and employment disparities between the latter region and the rest of the country. Thus, the National Development Plan for 2000-2006, announced in 1999, identified "balanced regional development" as a key plan objective. In furtherance of this objective, the government commissioned the Department of Environment and Local Government to prepare a National Spatial Strategy (NSS) that would identify a set of policy measures designed to shape the country's long-term spatial 
development. This strategy was eventually launched in November 2002 (Government of Ireland 2002).

In approach and tone, the NSS was very strongly influenced by the European Spatial Development Perspective. Thus, in place of the redistributive focus of the regional industrial plans of the 1970s, the NSS sought to develop the capability of the individual Irish regions to exploit the opportunities created by the globalisation process in order to participate directly in the international market place. This would be achieved through the cultivation of regionally specific capabilities that would both foster local entrepreneurship and attract mobile international investment. Regional development would be focused on the main regional cities whose traditional role as subordinate centres in the national urban hierarchy would be superceded by a new role as "gateways" linking their respective regions directly to the global economy. The aim was to establish in each of these gateway cities specialised clusters of business activities and support infrastructures that would achieve the "critical mass" which would allow them to compete sustainably in global markets.

In short, the NSS proposed to effect, over a 20 -year period, nothing less than a major restructuring of the Irish space economy, whereby the historic core/periphery structure focused on Dublin would be replaced by a new polycentric structure built around relatively autonomous cityregions (Davoudi and Wishardt 2005). We see here a clear enunciation of the kind of "competitive city-regionalism" which Ward and Jonas (2004) have identified as a key element of the new post-Fordist European territorial order. The NSS therefore constitutes what Brenner (2004b:473-474) terms a "glocalising scale-making project" whose central goal is "to position strategic local spaces competitively within global or supranational circuits of capital accumulation".

\section{Implementing the National Spatial Strategy}

The prospects of the NSS's ambitious aims ever achieving fruition have been profoundly compromised by the existence of powerful forces that had both created, and been created by, the established economic and political spatiality of the Irish state-what Brenner (2004b:455) has termed the "entrenched morphology" of existing state spatial organisation. The fundamental conflicts between the visions and assumptions of the mainly academic consultants who had provided the central thrust of the NSS and the perceived self-interest of both the political and bureaucratic actors who would have responsibility for its implementation were already apparent in the NSS document itself, and became even more so as the aftermath of the strategy's publication unfolded. Two key aspects of the NSS document reflect the tensions being referred to here: the selection of gateway cities and 
the governance structures required for effective implementation of the strategy.

According to the NSS document, the identification of gateway cities should be based on their potential for achieving the critical mass that would allow them to compete effectively with Dublin and other cities overseas for investment on an ongoing basis. However, in its treatment of this issue, the document is extraordinarily inconsistent. On the one hand, it expresses doubts about whether even Cork, Ireland's second city, with a population of 186,000 , possessed the base of firms, support services and facilities required to achieve critical mass. Indeed, the document goes on to suggest that the four largest provincial cities (Cork, Limerick, Galway and Waterford) might be developed as an "inter-connected and developed network of co-operating and complementary cities" (p 45), thus echoing the argument advanced by Ward and Jonas (2004) that neighbouring city-regions must collaborate in order to survive and compete in the globalised economy. According to the document, such a network, with a combined population of some one million people, offered the "best prospects for establishing critical mass of the type and scale capable of competing with that of the Greater Dublin Area" (p 45). Yet, despite the fact that none of the four largest provincial urban cities were thought to approach the level of critical mass required to function effectively as gateway centres, the NSS goes on to identify four further potential gateways, including a combination of small neighbouring towns in the midlands and a rather hypothetical partnership between Letterkenny in County Donegal and the much larger Derry, located in Northern Ireland (Figure 3 and Table 1).

There is obvious evidence here of the kind of politically motivated proliferation of designated centres which has repeatedly diluted and undermined attempts at spatially selective investment programmes the world over since the 1960s (Parr 1999). This is further indicated by the fact that the NSS also identifies nine "hub" towns which are seen as "supporting" the national and international role of the gateways and in turn "energising" smaller towns and rural areas within their sphere of influence ( $\mathrm{p} \mathrm{12)}$; recognises that many other county and larger sized towns in Ireland are "critical elements" in the structure for realising balanced regional development ( $\mathrm{p} 38$ ); and envisages that various medium-sized towns in each region will act as "local capitals" providing a range of services and opportunities for employment (p 12). While these passages may simply be window-dressing designed to mollify the population located outside the designated gateways, they nevertheless attest to the profound difficulties attending any attempt at a spatially selective approach to regional development in Ireland.

A second major deficiency in the NSS document is its failure to address the governance structures required for the effective implementation of the strategy. The kind of gateway development 


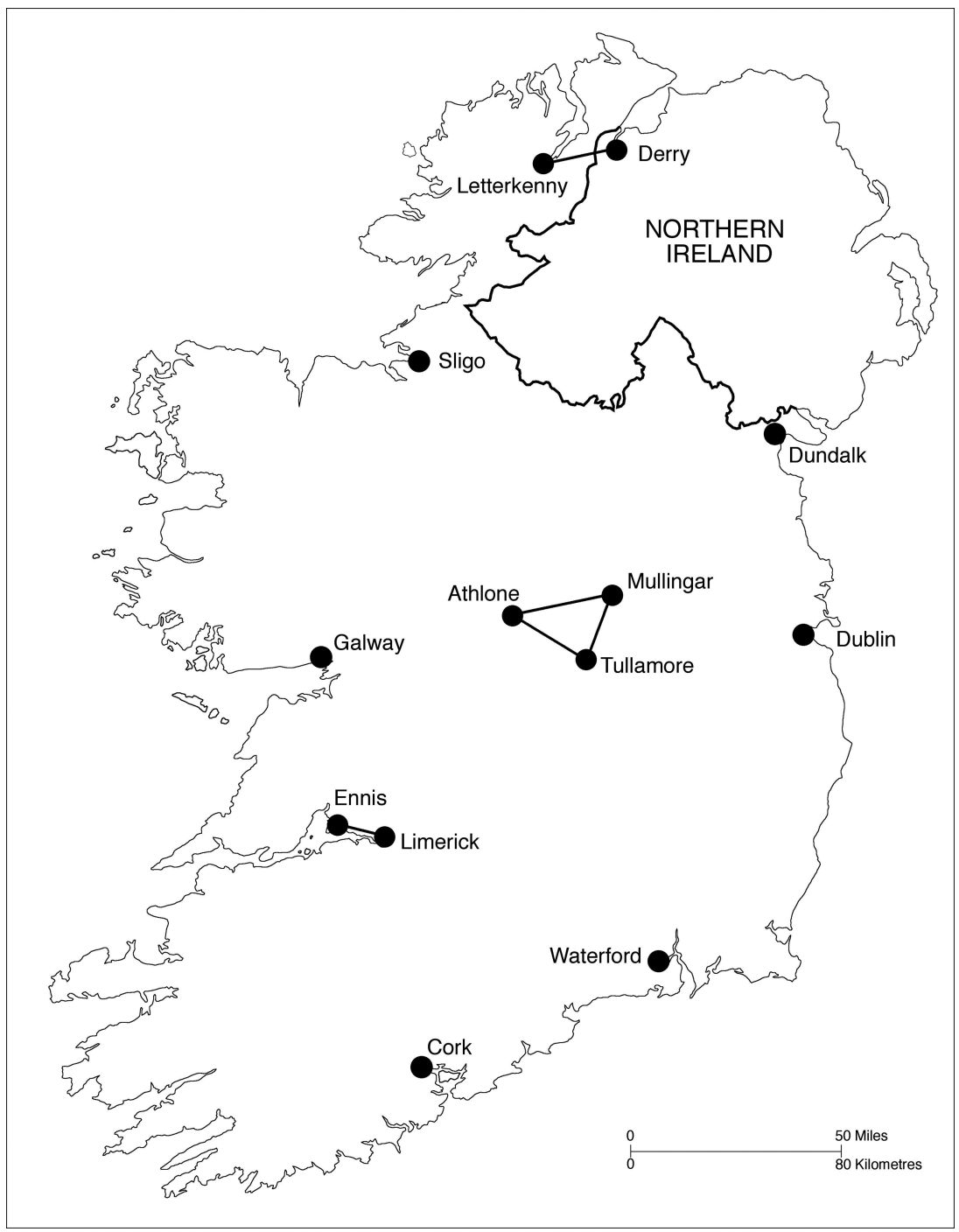

Figure 3: National Spatial Strategy gateway centres

envisaged by the NSS (including the forging of strong mutually supporting links between the gateways themselves and between the gateways and their hinterlands) requires forms of governance capable not just of coordinating a wide range of economic, social and infrastructural activities and facilities at regional level, but of driving such coordination. Elsewhere in Europe, according to Brenner (1998), the promotion of cities and regions as sites for transnational capital investment has involved the devolution to such cities and regions of a range of formerly centralised functions and responsibilities in order to 
Table 1: 2002 Populations of gateway cities identified in the National Spatial Strategy

\begin{tabular}{ll}
\hline Cork & 186,200 \\
Letterkenny/Derry & 99,100 \\
(Letterkenny) & $(15,200)$ \\
Limerick & 87,000 \\
Galway & 66,200 \\
Waterford & 46,700 \\
Athlone/Mullingar/Tullamore & 43,000 \\
Dundalk & 32,300 \\
Sligo & 19,400 \\
\hline
\end{tabular}

Source: Census of Population (2002).

allow these places to directly and effectively mobilise local resources in pursuit of such investment. Through this new functionality, "local and regional states ... are acquiring increasing structural significance within each territorial state's internal administrative-organizational hierarchy" (Brenner 1998:16).

There has been no parallel devolution of this kind in Ireland, where there is no effective tier of regional government, where local government has a minimal range of functions, where most elements of gateway development (enterprise promotion, health and education, transport, communications and energy) are centrally controlled, and where structures for managing and coordinating the implementation of public policy at territorial level are extremely weak (Laffan 1996). The NSS never addresses this issue, instead satisfying itself by calling for voluntaristic co-operation between local authorities which, in the absence of a regional governance structure ${ }^{1}$ and with very few relevant development functions residing at local government level, offers little prospect of effective gateway development.

The NSS's proposed designation as gateways of urban centres which have no prospect of attaining critical mass, and the failure to propose new governance structures which would involve devolution of an array of significant powers from central control, indicates the continued dominance in the Irish state structure of those interests favouring, on the one hand, spatial dispersal of public largesse (ie politicians) and on the other hand, continued centralisation of the control of largesse dispersal (the central bureaucracy). We can see here how a vision for a new spatiality for the Irish state which offers the possibility of more effective economic development at both national and regional levels in the long term has virtually no chance of realisation when set against this powerful coalition of political and bureaucratic interests favouring the status quo.

The lack of commitment - if not indeed downright opposition-to the NSS on the part of the Irish state apparatus is clearly apparent from 
the fate of the NSS since its launch in 2002. Despite a commitment, explicitly stated in the NSS document, that the NSS would be embedded in the policies and programmes of all government departments and agencies, this simply has not happened; in fact, most government programmes have behaved as if the NSS did not exist. For example, in the roll-out of the National Development Plan 2000-2006 (which identified balanced regional development as a key objective to be achieved via a gateway-based spatial strategy), there was little regard to regional development considerations in the allocation of funding for projects, while no specific measures for developing the gateway centres were implemented (Fitzgerald et al 2003). Indeed, in the final review of the Plan, conducted by the Department of Finance, the issue of regional development was not addressed at all and the word "gateway" appears nowhere in the document.

Perhaps the most blatant instance of the ignoring of the NSS in government policy thinking was an announcement, in December 2003 (1 year after the NSS was launched) by the Minister for Finance of a radical plan to relocate the headquarters of eight government departments and 10,300 civil service staff out of Dublin to provincial locations. One might have expected these headquarters functions, as well as at least a significant fraction of the relocated personnel, to be allocated to the gateway centres identified in the NSS, especially since the NSS document contains an express commitment that the government "will take full account of the NSS in moving forward the progressive decentralisation of Government offices and agencies" (Government of Ireland 2002:120). In fact, none of the headquarters functions, and only $13 \%$ of the jobs, were allocated to gateway centres; the balance of the jobs, and all the headquarters functions, were dispersed among no less than 48 locations outside the designated gateway towns. Davoudi and Wishardt (2005) have suggested that this was intended to forestall the possible loss by the government of political support in towns which had not been named as gateways or hubs in the NSS. There is further evidence here of how the intense localism of Irish politics has created a "mismatch between long-term goals and short-term political expediency", with the resulting "policy fragmentation and opportunism" (Davoudi and Wishardt 2005:132) undermining the implementation of the NSS.

\section{Discussion}

Brenner (1998) has suggested that the key role of the nation-state today is to provide an institutional framework to allow city-regions to enhance their capabilities of attracting mobile investment and competing in the global economy. There is a very considerable literature which argues that the key elements of such a framework should be the devolution from the central state to the regions not only of the functions required to achieve 
this capability enhancement but of political control over these functions (Cooke and Morgan 1998; Jones 2001; Morgan 1997; Pike 2004). To the extent that these arguments are valid, the continued adherence of the Irish state to a rigidly centralised political-administrative system has the effect of preserving a spatiality which is dysfunctional with respect to the emerging developmental needs of the space economy. This, then, raises the question as to how, and by whom, changes can be wrought in order to correct this dysfunctionality.

According to Brenner (2004b:455), new state spatialities emerge where modernising forces possess the strength to modify the preexisting spatial order "significantly enough to create qualitatively new geographies of state territorial organization and/or state regulatory activity", in the face of opposition from what Lipietz (1994) terms the "conservative defenders of the old spaces". In Ireland, such modernising forces simply do not exist. Put simply, the strength and competence of the central state and the culture of dependence articulated through the entrenched system of clientelism have stifled innovation and creativity and profoundly undermined local initiative and capacity, thus effectively blocking the emergence of countervailing forces from within civil society (Laffan 1996; Nanetti 1996). Nor are such forces likely to emerge from the business sector, with indigenous petty capital strongly intertwined with the party political system and the foreign sector remaining aloof from intervention in the conduct of local public affairs.

It may be, therefore, that some form of crisis is required to effect fundamental change in the spatiality of the Irish state. As Brenner (2004b:457) has observed: "During periods of sustained economic crisis, extant frameworks of urban governance may be viewed as ineffectual, and powerful social forces may promote the reorganization of inherited local and/or regional state structures." One possible source of crisis would be a situation where the failure of the Irish regions to mobilise their competitive capabilities would see them being reduced to marginalised backwaters while the Dublin region continued to develop its global role built upon its growing base of foreign-owned high-tech manufacturing and service activities (Breathnach 2000). An alternative scenario would see the Dublin region itself losing its ability to continue to attract high levels of inward investment due to problems of congestion deriving from a combination of overdevelopment and poor transport, settlement and environmental planning. Given Dublin's dominant role as a location for inward investment in recent years, such an outcome would constitute a crisis situation of truly national proportions.

A third possible source of fundamental political change is the current (early 2009) economic crisis which has affected Ireland more deeply than most other European economies, in large part due to the failure of the Irish government to rein in the cavalier investment behaviour of the intertwined banking and property development sectors, leading to a 
pile-up of toxic debt and the virtually total collapse of the banks' share value. The manner in which the government allowed this crisis to develop, and its feeble attempts to deal with the crisis when it did come to a head, have given rise to a serious public debate concerning the capacity of the current Irish political system to deal with major national crises of this type. A key focus of this debate has been the calibre of personnel elected to parliament primarily on the basis of their ability to look after the needs of local constituents. Significantly, the state bureaucracy has also been subjected to some sharp criticism over its poor regulatory performance and its apparently "cosy" relationship with elements of the business sector. There has been talk of electoral reform which would produce parliamentary representatives with a stronger focus on national issues and policies. Were this to occur, not only would it ring profound changes in Irish political culture, but it would also engender a different type of relationship between the political and bureaucratic sectors which might lead to long-term changes in the balance of power between the two.

\section{Conclusion}

This paper has demonstrated the dangers of overgeneralising the outcomes of the putative trend towards a "new regionalism" among west European states in the era of post-Fordist neoliberalism. The case of Ireland shows that rumours of the demise of the nation-state are greatly exaggerated. What makes this case particularly significant is that Ireland was considered to be the most globalised economy in the world by Foreign Policy magazine in 2004, yet has managed to avoid the movement towards political decentralisation which some have seen as the inevitable outcome of the globalisation process. This points to the importance of "context specificity", a key element of Pike's (2004:2145) "heterodox" approach to the study of regional governance which "seeks explicitly to recognise the particularities of place shaped by specific historical trajectories of economic, social, political, and cultural change". In particular, the Irish case corroborates the argument advanced by Ward and Jonas (2004: 2134) that:

the trend-geographically uneven as it is-towards competitive cityregionalism is best understood as representing an ongoing, dynamic, and conflict-ridden politics of and in space (which, in turn, is "scaled" in a variety of ways) rather than a smooth switch to a new postnational era of capitalist territoriality.

\section{Endnote}

1 There is a tier of so-called regional authorities, established in 1994 for the purpose of monitoring the spending, at regional level, of EU structural funding. While these are identified in the NSS as having a "major" role to play in the implementation of the 
strategy, in fact they are largely ineffectual institutions, with minimal staffing and no powers (Fitzpatrick Associates 1997).

\section{References}

Amin S (1976) Unequal Development. New York: Monthly Review Press

Breathnach P (1982) The demise of growth centre policy: The case of the Republic of Ireland. In R Hudson and J Lewis (eds) Regional Planning in Europe (pp 35-56). London: Pion Ltd

Breathnach P (1988) Uneven development and capitalist peripheralisation: The case of Ireland. Antipode 20:122-141

Breathnach P (1992) "The sad saga of local government reform in Ireland." Paper to conference on The State of the Irish Political System, University College, Cork, May

Breathnach P (2000) Globalisation, information technology and the emergence of niche transnational cities: The growth of the call centre sector in Dublin. Geoforum 31(4):477-485

Breathnach P (2007a) Inward investment to Ireland. In S Hodgett, D Johnson and S A Royle (eds) Doing Development Differently: Regional Development on the Atlantic Periphery (pp 132-149). Sydney: Cape Breton University Press

Breen R, Hannan D, Rottman D and Whelan C (1990) Understanding Contemporary Ireland. Dublin: Gill and Macmillan

Brenner N (1998) Global cities, glocal states: Global city formation and state territorial restructuring in contemporary Europe. Review of International Political Economy $5: 1-37$

Brenner N (2004a) New State Spaces: Urban Governance and the Rescaling of Statehood. Oxford: Oxford University Press

Brenner N (2004b) Urban governance and the production of new state spaces in western Europe, 1960-2000. Review of International Political Economy 11:447-488

Colin Buchanan and Partners (1968) Regional Studies in Ireland. Dublin: An Foras Forbartha

Committee on Spatial Development (1999) European Spatial Development Perspective: Towards Balanced and Sustainable Development of the Territory of the European Union. Luxembourg: Office for Official Publications of the European Communities

Cooke P and Morgan K (1998) The Associational Economy. Oxford: Oxford University Press

Davoudi S and Wishardt M (2005) The polycentric turn in the Irish spatial strategy. Built Environment 31(2):122-132

FitzGerald J, McCarthy C, Morgenroth E and O'Connell P (2003) Mid-term Evaluation of the National Development Plan and Community Support Framework for Ireland, 2000-6. Dublin, Economic and Social Research Institute

Fitzpatrick Associates (1997) Mid-term Evaluation: Regional Impact of the Community Support Framework for Ireland. Dublin: Fitzpatrick Associates Economic Consultants

Gill G (2008) Bourgeoisie, State, and Democracy. Oxford: Oxford University Press

Government of Ireland (2002) National Spatial Strategy for Ireland 2002-2020. Dublin: The Stationery Office

Gualini E (2004) Regionalization as "experimental regionalism": The rescaling of territorial policy-making in Germany. International Journal of Urban and Regional Research 28(2):329-353

Harvey D (1982) The Limits to Capital. Chicago: University of Chicago Press

Hazelkorn E (1986) Class, clientelism and the political process in the Republic of Ireland. In P Clancy, S Drudy, K Lynch and L O'Dowd (eds) Ireland: a Sociological Profile (pp 326-343). Dublin: Institute of Public Administration 
Held D, McGrew A, Goldblatt D and Perraton J (1999) Global Transformations. Cambridge: Polity

Jessop B (1990) State Theory. Cambridge: Polity

Jessop B (1994) Post-Fordism and the state. In A Amin (ed) Post-Fordism: A Reader (pp 251-79). Oxford: Blackwell

Jessop B (2002) The Future of the Capitalist State. Cambridge: Polity

Jones M (2001) The rise of the regional state in economic governance: "Partnerships for prosperity" or new scales of state power? Environment and Planning A 33:1185-1211

Keating M (1998) The New Regionalism in Western Europe. Cheltenham: Edward Elgar

Kirby P (1997) Poverty amid Plenty: World and Irish Development Reconsidered. Dublin: Trócaire and Gill \& Macmillan

Laffan B (1996) Ireland: A region without regions-the odd man out? In L Hooghe (ed) European Integration, Cohesion Policy, and Subnational Mobilisation (pp 320-341). Oxford: Oxford University Press

Lipietz A (1994) The national and the regional: Their autonomy vis-à-vis the capitalist world crisis. In R Palan and B Gills (eds) Transcending the State-Global Divide (pp 23-44). Boulder: Lynne Rienner Publishers

Loughlin J (2001a) The transformation of regional and local democracy in Western Europe. In J Loughlin (ed) Subnational Democracy in the European Union (pp 387400). Oxford: Oxford University Press

Loughlin J (2001b) The transformation of the democratic state in Western Europe. In J Loughlin (ed) Subnational Democracy in the European Union (pp 1-33). Oxford: Oxford University Press

MacKinnon D and Phelps N (2001) Devolution and the territorial politics of foreign direct investment. Political Geography 20(3):353-379

MacLeod G (2001) New regionalism reconsidered: Globalization and the remaking of political economic space. International Journal of Urban and Regional Research 25(4):804-829

Mjøset L (1992) The Irish Economy in a Comparative Institutional Perspective. Dublin: National Economic and Social Council Report No. 93

Morgan K (1997) The learning region: Institutions, innovation and regional renewal. Regional Studies 31(5):491-503

Nanetti RY (1996) EU cohesion and territorial restructuring in the nation states. In L Hooghe (ed) Cohesion Policy and European Integration: Building Multi-level Governance ( $\mathrm{pp}$ 59-88). Oxford: Oxford University Press

Ohmae K (1995) The End of the Nation State. London: Harper Collins

Parkinson M, Harding A and Dawson J (1994) Introduction: the changing face of urban Europe. In A Harding, J Dawson, R Evans and M Parkinson (eds) European Cities towards 2000 (pp 1-16). Manchester: Manchester University Press

Parr J B (1999) Growth pole strategies in regional economic planning: A retrospective view. Part 2: Implementation and outcome. Urban Studies 36(8):1247-1268

Pike A (2004) Heterodoxy and the governance of economic development. Environment and Planning A 36:2141-2161

Sharpe L (1988) Local government reorganisation: General theory and UK practice. In B Dente and F Kjellberg (eds) The Dynamics of Institutional Change: Local Government Reorganisation in Western Democracies ( $\mathrm{pp}$ 89-129). London: Sage

Stöhr W (1989) Regional policy at the crossroads: An overview. In L Albrechts, F Moulaert, P Roberts and E Swyngedouw (eds) Regional Policy at the Crossroads (pp 191-197). London: Jessica Kingsley

Ward K and Jonas AE (2004) Competitive city-regionalism as a politics of space: A critical reinterpretation of the new regionalism. Environment and Planning A 36:2119-2139 